\title{
THE RELEVANCE OF MEDICAL LABORATORY DIAGNOSIS IN CORONAVIRUS IN SUSPECTED HUMAN CASES
}

\author{
NNODIM JOHNKENNEDY ${ }^{1 *}$, EDWARD UKAMAKA ${ }^{1}$, DUNGA KINGSLEY EXCEL ${ }^{2}$, NJOKUOBI TREASURE ${ }^{3}$, \\ NJOKU CHUKWUDI JOSEPH ${ }^{4}$, UDUJIH HELEN IFEOMA ${ }^{1}$
}

\begin{abstract}
${ }^{1}$ Department of Medical Laboratory Science, Faculty of Health Science, Imo State University, Owerri. ${ }^{2}$ Department of Medical Laboratory Science, Madonna University Elele Rivers State Nigeria. ${ }^{3}$ Department of Microbiology, Faculty of Science, Imo State University, Owerri. ${ }^{4}$ Department of Pharmacology, Faculty of Basic Medical Sciences, Niger Delta University Amassoma, Bayelsa State Nigeria.
\end{abstract} Email: johnkennedy23@yahoo.com

Received: 06 April 2020, Revised and Accepted: 22 May 2020

ABSTRACT

Coronaviruses are a large family of viruses that are known to cause illness ranging from the common cold to more severe diseases such as Middle East Respiratory Syndrome (MERS) and Severe Acute Respiratory Syndrome. Coronavirus disease (Covid-19) is an infectious disease caused by a new virus. It leads to respiratory illness with symptoms such as a cough, fever, and in more severe cases, difficulty breathing. One can be protected by washing hands regularly, avoiding touching your face, and avoiding close contact with individuals who are unhealthy. It is transmitted through contact with an infected individual when they cough or sneeze. It could be transmitted when an individual touches a surface or object that has the virus on it, then touches the eyes, nose, or mouth. Some laboratory test to diagnose covid-19 includes real-time RT-PCR primer and probe and CDC serology test. It is very necessary that covid-19 is diagnosed for accurate treatment and management.

Keywords: Covid-19, Laboratory test, Humans.

\section{INTRODUCTION}

Coronavirus can be called covid-19. It is a pandemic infection which can cause immediate, mild upper lung infection. This covid-19 was discovered in December 2019 in Wuhan, China [1]. The rate of spread of this pandemic is unprecedented. The whole world is indeed challenged by this global infection. These viruses are mainly consist of various RNA virus in the Coronaviridae family. They are subclassed into four genera: Alpha, beta, gamma, and delta. They result in disease of placid to harsh cases in human and animal. Although the endemic human coronavirus such as alphacorona virus and betacorona viruses can lead to influenzalike illness or pneumonia in humans, while viruses in the genera Gammaand deltacoronavirus primarily infect birds but not exclusively [2].

Some clinical symptoms and manifestations

Covid-19 could attack the trachea through the organ of smell. This could happen between the incubation period of 7-10 days. It is pertinent to note that after this period, nasal obstruction, sneezing, runny nose, and occasionally dry cough can result [3]. This can lead to the shedding of the virus in the nasal secretions. On the other hand, this covid-19 may lead to disease of the lower airways [4].

These coronaviruses are highly picky and grow only in differentiated respiratory epithelial cells according to studies in both organ cultures and human volunteers. Consequently, infected cells yield vacuolation. It then shows damaged cilia and may produce syncytia [5]. This impairment of cells could lead to the production of inciting mediators. This leads to increased temperature of the mucosa as well as nasal secretion resulting in swelling and inflammation. Consequently, obstruction of air ways and sneezing are stimulated [6].

At the initial stage, individuals infected with the virus may display no symptoms. However, some symptoms such as fever, dry cough, fatigue, and briefness of breath may be indicated later [7]. Other symptoms which may be dangerous include difficulty in respiration, constant chest ache or stress, uncertainty, inability to wake with ease, and bluish countenance. It important to note that runny nasal secretions, increased sneezes, or sore throat may be seen. In fact, symptoms such as nausea, vomiting, and diarrhea may be in different ranges [8].
It is important to note that the period between the moment when someone is attacked with the virus and the time when the symptoms begin to manifest [9]. This is the incubation time. The incubation time for coronavirus is 7-10 days, but may fall between 4 and 14 days [10].

\section{Laboratory tests for covid-19}

Themedicallaboratory diagnostic tests for coronavirus includemolecular tests and serology tests. This means diagnostic testing for covid-19 is undertaken using two varied approaches which are Whole Genome Sequencing and Real-Time Reverse Transcriptase PCR (RT-PCR) [11]. Meanwhile, almost all diagnostic testing for covid-19 is done using RT-PCR [12].

The clinical and outbreak control should be guided by a medical laboratory scientist, where suspected cases must be vetted for the virus with nucleic acid amplification tests (NAATs), such as RT-PCR. The decision to test must come from clinical and epidemiological factors and associated with a calculation of the likelihood of infection [13]. PCR testing can be considered in the evaluation of persons who have had contact with a coronavirus case [14].

The medical laboratories carrying out the testing for the coronavirus should follow strict biosafety practices. NAAT detects the standard sequence of the virus RNA such as real-time reverse-transcription polymerase chain reaction (RT-PCR) with confirmation to nucleic acid sequencing when necessary [15]. The laboratory testing includes the following steps:

\section{Determining confirmation}

To consider a case as confirmed, the following needs to be ensured, where the virus is not prevalent. A positive NAAT results for at least two different targets on the genome, of which at least one target is likely more specific, or one positive NAAT result for the presence of beta coronavirus. Coronavirus is can be further identified by sequencing the genome of the virus $[15,16]$.

\section{Serological testing}

Serological testing can aid the diagnosis of an ongoing outbreak and retrospective evaluation. In cases, where NAAT assays are negative, and 
there is a strong epidemiological connection to coronavirus infection, paired serum samples can support the diagnosis that once validated tests are accessible. Serum specimen can be stored for these purposes [17].

\section{Viral sequencing}

In fact, providing confirmation of the presence of the virus, sequencing of a percentage of sample from clinical cases, is important to monitor for viral genome mutations [18]

\section{Viral culture}

Virus isolation may not be recommended as a diagnostic procedure [19]

\section{Coronavirus diagnostic test kits}

Various companies worldwide are manufacturing the coronavirus diagnostic test kits, including:

1. GenMark Diagnostics, Inc. - ePlex Research Use Only (RUO) test kits are provided by GenMark company.

2. BioFire Diagnostics - Film Array ${ }^{\circledR}$ Respiratory (RP and RP2) Panels. It is called BioFire Respiratory Panels. They are tests made to help clinicians quickly diagnose respiratory infections, which add up to a significant health care burden and present with nearly indistinguishable symptoms.

3. Cephied Inc. - This company is for the development of a test for the Coronavirus Strain (2019-nCoV). The test will be designed for use on any of its 23,000 GeneXpert Systems placed worldwide and is likely to deliver point-of-care results in about $30 \mathrm{~min}$.

4. Meridian Biosciences creates a "Master Mix." This works as the building blocks for rapid testing of the coronavirus. The kit tests RNA similar to how tests are done for influenza [20].

\section{Sample Collection}

The process of sample collection is as follows:

A. Safety during sample collection

It is very necessary to ensure that safe collection mechanisms are in use. The workforce must be adequately trained for suitable sample collection, storage, packaging, and transport. Specimens collected for diagnosis must be considered as possibly infectious material [19].

B. The sample to be collected

Mostly airways specimen must be collected, either upper respiratory or lower respiratory samples. Besides this, other medical sample may be collected as the virus had been reported in blood and feces [18]

C. Packaging and shipment of clinical sample In fact, the correct handling samples and its storage in $2-8^{\circ} \mathrm{C}$ are important. Transport of the samples within the country should adhere with applicable national regulations [10].

\section{Prevention}

One can be protected and prevented from spreading the virus to others through:

- Washing of hands frequently for $20 \mathrm{~s}$, with the aid of soap and water as well cleaning the hands with sanitizers.

- Covering of nose and mouth with a non-reusable tissue or bend elbow during coughing as well as sneezing sneezing.

- Avoiding getting in touch physically with individuals who are unhealthy.

- Staying home when feel unhealthy and restrain from others.

- Avoiding touching the organ of sight, organ of smell, as well as mouth if the hands are dirty as well as adhering strictly to appropriate biosafety practices [21].

\section{CONCLUSION}

Coronaviruses have complex or specific nutritional requirements and grow only in specific airway epithelium cells. Infected cells result to essentially enclosed compartments which are filled with water containing inorganic and organic molecules, show damaged cilia and may form a multinucleate mass of cytoplasm that is not separated into cells. Cell impairment brings about the release of inflammatory attackers, which enhances nasal secretion and causes irritation and swelling. These responses lead to obstruction of the airways, increase the temperature of the mucosa and sneezing. Hence, there is a need to do laboratory test for proper guidance.

\section{REFERENCES}

1. Hui DS, Azhar E, Madani TA, Ntoumi F, Kock R, Dar O, et al. The continuing 2019-nCoV epidemic threat of novel coronaviruses to global health-the latest 2019 novel coronavirus outbreak in Wuhan, China. Int J Infect Dis 2020;91:264-66.

2. Wang W, Tang J, Wei F. Updated understanding of the outbreak of 2019 novel coronavirus (2019-nCoV) in Wuhan, China. J Med Viro 2020;92:441-7.

3. Chughtai A, Malik A. Is coronavirus disease (COVID-19) case fatality ratio underestimated? Glob Biosecur 2020;1:2-7.

4. Yi-Chi W, Ching-Sung C, Yu-Jiun C. The outbreak of COVID-19: An overview. J Chin Med Assoc 2020;83:217-20.

5. Zhang L, Liu Y. Potential interventions for novel coronavirus in China: A systematic review. J Med Virol 2020;92:479-90.

6. Chen N, Zhou M, Dong X, Qu J, Gong F, Han Y, et al. Epidemiological and clinical characteristics of 99 cases of 2019 novel coronavirus pneumonia in 6.Wuhan, China: A descriptive study. Lancet 2020;395:507-13

7. Huang C, Wang Y, Li X, Ren L, Zhao J, Hu Y. Clinical features of patients infected with 2019 novel coronavirus in Wuhan, China. Lancet 2020;395:497-506

8. Chih-Cheng L, Tzu-Ping S, Wen-Chien K, Hung-Jen T, Po-Ren H Severe acute respiratory syndrome coronavirus 2 (SARS-CoV-2) and coronavirus disease-2019 (COVID-19): The epidemic and the challenges. Int J Antimicrob Agents 2020;55:105924.

9. Moriyama M, Hugentobler WJ, Iwasaki A. Seasonality of respiratory viral infections. Ann Rev Virol 2020;7:44-6.

10. Kampf G, Todt D, Pfaender S, Steinmann E. Persistence of coronaviruses on inanimate surfaces and their inactivation with biocidal agents. J Hosp Infect 2020;104:246-51.

11. $\mathrm{Xu} \mathrm{H}$, Zhong L, Deng J, Peng J, Dan H, Zeng X, et al. High expression of ACE2 receptor of 2019-nCoV on the epithelial cells of oral mucosa. Int J Oral Sci 2020;12:8

12. Heymann DL, Shindo N, WHO Scientific and Technical Advisory Group for Infectious Hazards. COVID-19: What is next for public health? Lancet 2020;395:542-5.

13. Zhou F, Yu T, Du R, Fan G, Liu Y, Liu Z. Clinical course and risk factors for mortality of adult inpatients with COVID-19 in Wuhan, China: A retrospective cohort study. Lancet 2020;395:1054-62.

14. Cohen J, Normile D. New SARS-like virus in China triggers alarm. Science 2020;367:234-5.

15. Anderson RM, Heesterbeek H, Klinkenberg D, Hollingsworth TD How will country-based mitigation measures influence the course of the COVID-19 epidemic? Lancet 2020;395:931-4.

16. Cheng ZJ, Shan J. 2019 Novel coronavirus: Where we are and what we know. Infection 2020;48:155-63.

17. Spackman E, Senne DA, Myers TJ. Development of a real-time reverse transcriptase PCR assay for type a influenza virus and the avian $\mathrm{H} 5$ and H7 hemagglutinin subtypes. J Clin Microbiol 2002;40:3256-60.

18. Bustin SA. Absolute quantification of mRNA using real-time reverse transcription polymerase chain reaction assays. J Mol Endocrino 2000;25:169.

19. Hierro N, Esteve-Zarzoso B, González A, Mas A, Guillamón JM Real-time quantitative PCR (QPCR) and reverse transcription-QPCR for detection and enumeration of total yeasts in wine. Appl Environ Microbiol 2006; 72:7148-55

20. Slomka MJ, Pavlidis T, Coward VJ. Validated RealTime reverse transcriptase PCR methods for the diagnosis and pathotyping of Eurasian H7 avian influenza viruses. Influenza Other Respir Viruses 2009;3:151-64.

21. Lu H. Drug treatment options for the 2019-new coronavirus (2019nCoV). Biosci Trends 2020;14:69-71. 